\title{
Case for diagnosis
}

\section{Caso para diagnóstico}

\author{
Nilton Di Chiacchio ${ }^{1}$ \\ Felipe Kezan Gabriel ${ }^{3}$ \\ Nilton Gioia Di Chiacchio ${ }^{4}$
}

\section{DISEASE HISTORY}

A 65-year-old black male patient from Sao Paulo presented with an injury, which had been present for a year, in the left foot due to having stepped on a piece of iron. He was treated with systemic antibiotherapy (azithromycin), with clinical improvement. Six months later, the patient noticed a painful lump with drainage of secretion, sometimes yellowish, sometimes purulent, on the site of the scar. For eight months, in addition to diagnostic investigation, he was treated with antibiotics and NSAIDs, with periods of improvement and aggravation. The patient had personal history of improperly treated hypertension and chronic alcoholism.

A dermatological examination showed the presence of suppurating fistula with hyperkeratotic border of about $2 \mathrm{~cm}$ in diameter in the left high arch. Around the lesion, brownish macules of varying sizes and unclear boundaries could be observed (Figure 1).

Direct mycological examination and fungal culture were negative.

An ultrasonography showed nodular image with calcic walls of $0.9 \mathrm{~cm}$ in diameter, $1 \mathrm{~cm}$ away from the skin, in the plantar arch, and another hypoechoic nodular area with bosselated contours, measuring $2.3 \times 2.5 \times 2.4 \mathrm{~cm}$ at

\author{
Susana Lu Chen Wu ${ }^{2}$ \\ Diego Leonardo Bet ${ }^{4}$
}

the level of the $4^{\text {th }}$ metatarsal bone, which invaded muscles (Figure 2). A CT scan revealed a hyperdense, heterogeneous, irregular nodular image close to the $2^{\text {nd }}$ metatarsal head, with no periosteal changes of a likely cartilaginous nature. Magnetic resonance revealed an aspect compatible with chronic inflammation associated with foci of inflammation / infection of fungal origin, in addition to small images of partially clear borders, which could be related to areas of edema.

Anatomopathological examination showed ulcerated, suppurating, chronic inflammation with extensive fibrosis. Research on fungi and $\mathrm{AFB}$ were negative.

Given these results and after careful observation of the dermatologic lesion (fistula with hyperkeratotic borders), the possibility of a foreign body was suggested and an exploratory surgery was carried out. After incision, the fistulous path was followed until a black fragment was found, identified as a piece of rubber (Figure 3). When enquired about it, the patient reported wearing black "Havaianas" sandals when the accident occurred, confirming the characteristics of the removed fragment.

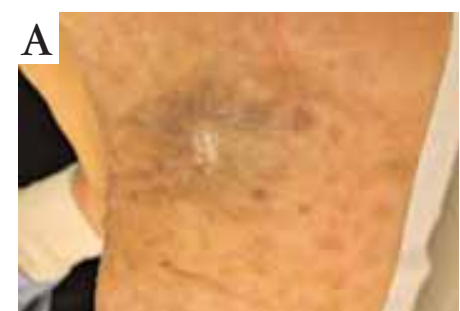

B

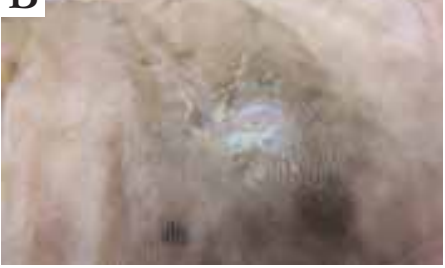

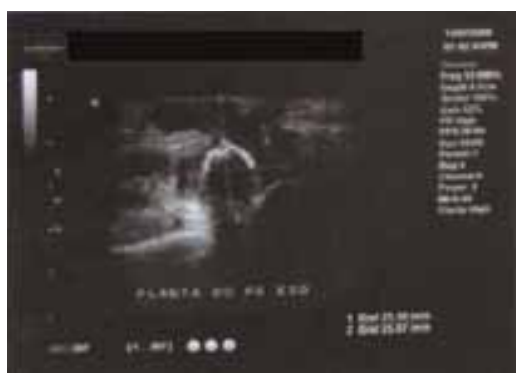

FIGURE 2: Ultrasonography of the plantar surface of the left foot showing hypoechoic nodular area with bosselated contours

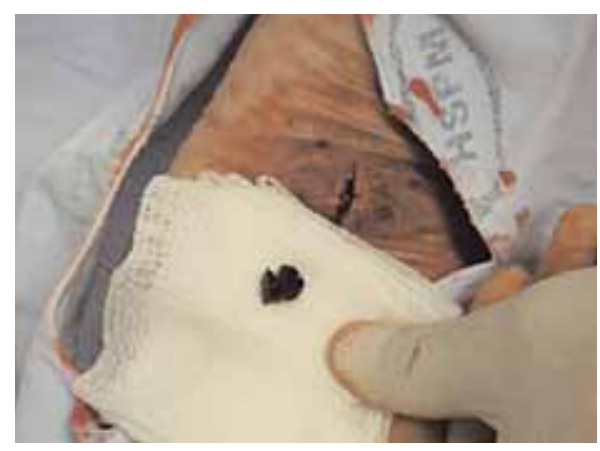

FIGURE 3: Removed foreign body - rubber

Figure 1:

A. Clinical feature of

plantar-surface lesion;

B. Details of the lesion

Approved by the Editorial Board and accepted for publication on 15.12.2010.

* Work conducted at Sao Paulo City-Civil-Servant Hospital (Hospital do Servidor Publico Municipal de Sao Paulo) - Sao Paulo (SP), Brazil.

Conflict of interest: None / Conflito de interesse: Nenhum

Financial funding: None / Suporte financeiro: Nenhum

Ph.D. in Dermatology, School of Medicine, University of Sao Paulo (USP) - Head of the Dermatology Clinic at the City-Civil-Servant Hospital (Hospital do Servidor Público Municipal) (HSPM-SP) - Sao Paulo (SP), Brazil.

Physician Assistant, Dermatology Clinic, Sao Paulo City-Civil-Servant Hospital - São Paulo (SP), Brazil

Resident Physician, Dermatology Clinic, Sao Paulo City-Civil-Servant Hospital - Sao Paulo (SP), Brazil.

Residents of the Dermatology Department, Taubaté School of Medicine, São Paulo, Brazil. 


\section{COMMENTS}

Cases of puncture lesions with foreign body in the feet are treated in emergency departments, dermatology and orthopedic clinics. ${ }^{1}$ Skin lesions resulting from plantar-surface foreign bodies, despite their frequent and repetitive characteristics, are rarely mentioned in textbooks or journals of dermatology, complicating the diagnosis. We found only one case report of a foreign body in the posterior nail fold, resulting from resin after bone graft, where the author describes the injury as a suppurating fistula with inflammatory signs. ${ }^{2}$ Differential diagnosis must be conducted with bone tumors and soft parts of the feet, ${ }^{3}$ furuncular myiasis, ${ }^{4}$ acral lentiginous melanoma ${ }^{5}$ and deep mycoses. ${ }^{6}$

Direct mycological exams, fungal cultures and histopathological exams help to differentiate it from fungal infections and neoplasms. Despite the possibility of isolation of opportunistic fungi, these fungi disappear after removal of the foreign body. ${ }^{6}$

Ultrasonography is the most useful imaging method in the diagnosis when compared with X-ray, CT scan and MRI.

Some complications due to delay in the diagnosis and treatment of the foreign body may be observed, such as plantar fascia lesions, ${ }^{8}$ superficial cellulitis, osteomyelitis, septic arthritis9 and secondary infections. ${ }^{10}$

Surgical removal of the foreign body is mandatory so that clinical improvement can be observed. $^{11}$

\begin{abstract}
Patients presenting with plantar puncture wounds with presence of foreign bodies are treated in emergency departments, dermatology and orthopedic clinics. The clinical features of these lesions are rarely cited in journals and textbooks of dermatology. We report a case of foreign body in the plantar surface of the foot, in which clinical history and dermatological examination were decisive for the diagnosis.

Keywords: Cutaneous fistula; Foreign bodies; Procedimentos cirúrgicos ambulatórios

Resumo: Pacientes com ferimentos penetrantes plantares com presença de corpo estranho são atendidos em serviços de emergência, clínicas ortopédicas e dermatológicas. As características clínicas dessas lesões são pouco citadas em periódicos e livros textos dermatológicos. Relatamos um caso de corpo estranho plantar em que a história clínica e o exame dermatológico foram decisivos para o diagnóstico.

Palavras-chave: Corpos estranhos; Fístula cutânea; Técnicas de diagnóstico por cirurgia
\end{abstract}

\section{REFERENCES}

1. Vollman D, Smith GA. Epidemiology of lawn-mower-related injuries to children in the United States, 1990-2004.Pediatrics.2006;118: 273-8.

2. Vidal S, Barcala L, Barberán J, Heras JA, Tovar JA, Baran R. A suppurating fistula from a cement foreign bodypresenting as a tumour of the nail. Acta Derm Venereol. 2000;80:313-4.

3. Brodsky JW; Toppins AC; Silverman JB. Between a rock and a hard place: a case of petrous foreign body simu-lating an intra-osseous tumor. Foot Ankle Int. 2006;27:993-7.

4. Adams DW; Cooney RT. Excision of a Dermatobia hominis larva from the heel of a South American traveler: a casereport. J Foot Ankle Surg. 2004; 43:260-2.

5. Soon SL, Solomon AR, Papadopoulos D, Murray DR, McAlpine B, Washington CV. Acral lentiginous melanoma

mimickingbenign disease: the Emory experience. J Am Acad Dermatol. 2003;48:183-8

6. Heins Vaccari EM, Lacaz CS, Rodrigues EG. Forma micetomatóide de infecçäo por Scedosporium apiospermum: registro de um caso. An Bras Dermatol. 1990;65:193-5.

7. Horton LK, Jacobson JA, Powell A, Fessell DP, Hayes CW. Sonography and Radiography of Soft-Tissue ForeignBodies. AJR. 2001; 176: 1155-9.

8. Jeswani T, Morlese J, McNally EG. Getting to the heel of the problem: plantar fascia lesions. Clin Radiol.2009;64:931-9.
9. Eidelman M, Bialik V, Miller Y, Kassis I. Plantar puncture wounds in children analysis of 80 hospitalized patientsand late sequelae. Isr Med Assoc J. 2003:5:268-71.

10. Joseph WS, Le Frock JL. Infections complicating puncture wounds of the foot. J Foot Surg. 1987; 26(1 Suppl): S30-3.

11. Sharma S, Azzopardi T. A Simple Surgical Technique for Removal of Radio-Opaque Foreign Objects From thePlantar Surface of the Foot. Ann R Coll Surg Engl. 2006;88:76.

\footnotetext{
MAILING ADDRESS / ENDEREÇO PARA CORRESPONDÊNCIA:

Nilton Di Chiacchio

Rua Dr. Cesar, 62, conj. 35, Santana

02013-000 São Paulo (SP), Brazil

E-mail:ndichia@terra.com.br
}

How to cite this article/Como citar este artigo: Di Chiacchio N, Wu SLC, Gabriel FK, Bet DL, Di Chiacchio NG. Case for diagnosis. Plantar-surface foreign body. An Bras Dermatol. 2011;86(1):165-72. 